\title{
Inositol 1,4,5-Trisphosphate Receptor Type 1 in Granule Cells, Not in Purkinje Cells, Regulates the Dendritic Morphology of Purkinje Cells through Brain-Derived Neurotrophic Factor Production
}

\author{
Chihiro Hisatsune, ${ }^{1,3}$ Yukiko Kuroda, ${ }^{3}$ Takumi Akagi, ${ }^{2}$ Takashi Torashima, ${ }^{4}$ Hirokazu Hirai, ${ }^{4}$ Tsutomu Hashikawa, ${ }^{2}$ \\ Takafumi Inoue, ${ }^{3,5}$ and Katsuhiko Mikoshiba ${ }^{1,3,5}$ \\ Laboratories for ${ }^{1}$ Developmental Neurobiology and ${ }^{2}$ Neural Architecture, RIKEN Brain Science Institute, Wako City, Saitama 351-0198, Japan, ${ }^{3}$ Division of \\ Molecular Neurobiology, Institute of Medical Science, The University of Tokyo, Minato-ku, Tokyo 108-8639, Japan, ${ }^{4}$ Innovative Brain Science Project, \\ Advanced Science Research Center, Kanazawa University, Kanazawa 920-8640, Japan, and ${ }^{5}$ Calcium Oscillation Project, International Cooperative Research \\ Project, Japan Science and Technology Agency, Chiyoda-ku, Tokyo 102-0084, Japan
}

Here, we show that cultured Purkinje cells from inositol 1,4,5-trisphosphate receptor type 1 knock-out (IP $\left.{ }_{3} \mathrm{R} 1 \mathrm{KO}\right)$ mice exhibited abnormal dendritic morphology. Interestingly, despite the huge amount of $\mathrm{IP}_{3} \mathrm{R} 1$ expression in Purkinje cells, IP ${ }_{3} \mathrm{R} 1$ in granule cells, not in the Purkinje cells, was responsible for the shape of Purkinje cell dendrites. We also found that BDNF application rescued the dendritic abnormality of $\mathrm{IP}_{3} \mathrm{R} 1 \mathrm{KO}$ Purkinje cells, and that the increase in BDNF expression in response to activation of AMPA receptor (AMPAR) and metabotropic glutamate receptor ( $\mathrm{mGluR}$ ) was impaired in $\mathrm{IP}_{3} \mathrm{R} 1 \mathrm{KO}$ cerebellar granule cells. In addition, we observed abnormalities in the dendritic morphology of Purkinje cells and in the ultrastructure of parallel fiber-Purkinje cell (PF-PC) synapses in IP ${ }_{3} \mathrm{R} 1 \mathrm{KO}$ mice in vivo. We concluded that activation of AMPAR and mGluR increases BDNF expression through $\mathrm{IP}_{3} \mathrm{R} 1$-mediated signaling in cerebellar granule cells, which contributes to the dendritic outgrowth of Purkinje cells intercellularly, possibly by modifying PF-PC synaptic efficacy.

Key words: dendrite outgrowth; $\mathrm{IP}_{3}$ receptor; $\mathrm{BDNF}$; Purkinje cell; granule cell; $\mathrm{Ca}^{2+}$ release

\section{Introduction}

The proper growth and branching of dendrites profoundly affects the formation of neural networks and neural functions. The spatial patterns of dendritic morphology determine the number and patterns of synapses received by individual neurons and the efficacy with which synaptic information is transmitted to the soma. The molecular mechanism that regulates the development of the dendritic arbor has been intensively examined recently, and numerous lines of evidence indicate that dendritic growth is a dynamic process that is regulated by various environmental cues, including synaptic activity and molecular signals from adjacent cells (Whitford et al., 2002; Wong and Ghosh, 2002; Miller and Kaplan, 2003; Konur and Ghosh, 2005; Redmond and Ghosh, 2005).

Inositol 1,4,5-trisphosphate receptors ( $\left.\mathrm{IP}_{3} \mathrm{Rs}\right)$ constitute a

\footnotetext{
Received July 29, 2006; revised Sept. 12, 2006; accepted Sept. 14, 2006.

This work was supported by grants from the Ministry of Education, Science, and Culture of Japan (K.M., T.I.), a Grant-in-Aid for Young Scientists (C.H.), and the Japan Science and Technology Agency. We thank all members of our laboratories, especially M. Iwai and A. Z. Suzuki for experimental materials, N. Ogawa for technical help, and Dr. A. Mizutani for fruitful discussions.

Correspondence should be addressed to Dr. Chihiro Hisatsune, Division of Molecular Neurobiology, Institute of Medical Science, The University of Tokyo, 4-6-1, Shirokane-dai, Minato-ku, Tokyo 108-8639, Japan. E-mail: chihiro@ims.u-tokyo.ac.jp.

D0I:10.1523/JNEUROSCI.3269-06.2006

Copyright $\odot 2006$ Society for Neuroscience $\quad$ 0270-6474/06/2610916-09\$15.00/0
}

family of $\mathrm{Ca}^{2+}$ channels that is responsible for $\mathrm{Ca}^{2+}$ mobilization from intracellular stores (Berridge et al., 2000), and three subtypes have been identified: $\mathrm{IP}_{3} \mathrm{R} 1, \mathrm{IP}_{3} \mathrm{R} 2$, and $\mathrm{IP}_{3} \mathrm{R} 3$ (Furuichi and Mikoshiba, 1995; Patel et al., 1999). IP ${ }_{3} R 1$ is the predominant subtype in the CNS, especially in cerebellar Purkinje cells (Furuichi et al., 1993). IP ${ }_{3}$ Rs have been shown to play crucial roles in several neuronal functions, including synaptic plasticity (Matsumoto et al., 1996; Inoue et al., 1998; Fujii et al., 2000; Nishiyama et al., 2000; Itoh et al., 2001), axonal extension (Takei et al., 1998), and nerve growth cone guidance (Xiang et al., 2002). However, in contrast to our knowledge of the role of $\mathrm{IP}_{3} \mathrm{R}$ mediated signaling in axon growth and guidance, it remains unknown whether $\mathrm{IP}_{3} \mathrm{R}$-mediated signaling contributes to shaping the dendrites of neurons.

In this study, we used $\mathrm{IP}_{3} \mathrm{R} 1$ knock-out $(\mathrm{KO})$ mice to examine the role of $\mathrm{IP}_{3} \mathrm{R} 1$-mediated signaling in the dendritic outgrowth of Purkinje cells. First, we discovered that Purkinje cells from $\mathrm{IP}_{3} \mathrm{R} 1 \mathrm{KO}$ mice exhibit abnormal dendritic morphology in culture, and by means of simple experimental techniques we demonstrated that the abnormal morphology of Purkinje cells was caused by a lack of $\mathrm{IP}_{3} \mathrm{R} 1$ in cerebellar granule cells rather than in Purkinje cells. We also observed a defect of the increase in BDNF production after AMPA receptor (AMPAR) and metabotropic glutamate receptor (mGluR) stimulation in $\mathrm{IP}_{3} \mathrm{R} 1 \mathrm{KO}$ cerebellar 
granule cells, and that exogenous application of BDNF rescued the abnormal morphology of $\mathrm{IP}_{3} \mathrm{R} 1 \mathrm{KO}$ Purkinje cells. In addition, we observed enlarged presynaptic terminals of parallel fiberPurkinje cell (PF-PC) synapses and vesicle accumulation in $\mathrm{IP}_{3} \mathrm{R} 1 \mathrm{KO}$ mice in vivo. Together, our findings strongly suggest that AMPAR and mGluR stimulation increases BDNF expression at least in part through $\mathrm{IP}_{3} \mathrm{R} 1$-mediated signaling in cerebellar granule cells, which intercellularly controls the dendritic outgrowth of Purkinje cells, possibly by altering PF-PC synaptic efficacy. Thus, our data provide an important clue to understanding the molecular basis of intercellular communication between neurons in shaping the dendritic morphology.

\section{Materials and Methods}

Cerebellar neuronal culture. Dissociated cerebellar neuron cultures were prepared from postnatal day $1(\mathrm{P} 1)$ to $\mathrm{P} 2$ wild-type (WT) and $\mathrm{IP}_{3} \mathrm{R} 1 \mathrm{KO}$ mice according to a method for rat Purkinje cell culture established previously (Furuya et al., 1998) with some modifications. Briefly, cerebellar cells were suspended in medium containing $10 \%$ fetal bovine serum at a density of $7.5 \times 10^{6}$ cells $/ \mathrm{ml}$. Forty microliters of the suspension were spotted (spots are $\sim 4-5 \mathrm{~mm}$ in diameter, resulting in $\sim 1.5-2.5 \times$ $10^{6}$ cells $/ \mathrm{cm}^{2}$ ) onto plastic coverslips ( $13.5 \mathrm{~mm}$ in diameter; Sumilon; Sumitomo Bakelite, Tokyo, Japan) coated with $200 \mu \mathrm{g} / \mathrm{ml}$ poly-L-lysine and placed in a humidified $\mathrm{CO}_{2}$ incubator $\left(5.0 \% \mathrm{CO}_{2}\right.$ at $\left.37^{\circ} \mathrm{C}\right)$. After $12 \mathrm{~h}$, serum-free medium was added to each well (final serum concentration, $1.0 \%$ ). The medium was composed of Eagle's minimal essential medium supplemented with $1.0 \mathrm{mg} / \mathrm{ml}$ bovine albumin (Sigma, St. Louis, MO), insulin-transferrin-serenium (Invitrogen, Carlsbad, CA), $0.1 \mathrm{~nm}$ L-tyroxine (T4) (Sigma), $1.0 \mu \mathrm{g} / \mathrm{ml}$ aprotinin (Sigma), $0.25 \%$ glucose, $100 \mu \mathrm{M}$ L-serine, $2.0 \mathrm{~mm}$ glutamine, $2.0 \mathrm{mg} / \mathrm{ml} \mathrm{Na}_{2} \mathrm{CO}_{3}, 100$ $\mathrm{U} / \mathrm{ml}$ penicillin, and $135 \mu \mathrm{g} / \mathrm{ml}$ streptomycin. To determine the effect of exogenous BDNF on dendritic outgrowth, $10 \mathrm{ng} / \mathrm{ml} \mathrm{BDNF}$ (Sigma) was added to culture from $9 \mathrm{~d}$ in vitro (div) for $5 \mathrm{~d}$.

For overlay assay, $40 \mu \mathrm{l}$ of cerebellar cell suspension in medium containing $10 \%$ bovine serum $\left(7.0 \times 10^{6} \mathrm{cells} / \mathrm{ml}\right)$ from either P7 WT or $\mathrm{IP}_{3} \mathrm{R} 1 \mathrm{KO}$ mice were spotted on the plastic coverslips. After $24 \mathrm{~h}, 10 \mu \mathrm{l}$ of cerebellar cells $\left(7.0 \times 10^{6}\right.$ cells $\left./ \mathrm{ml}\right)$ from $\mathrm{P} 1 \mathrm{IP}_{3} \mathrm{R} 1 \mathrm{KO}$ mice were spotted over the P7 cerebellar cells. After $24 \mathrm{~h}$, serum-free medium was added to each well. The final percentage of serum was $1.0 \%$.

Cerebellar glial cell culture was prepared from P1-P2 WT or $\mathrm{IP}_{3} \mathrm{R} 1 \mathrm{KO}$ mice cerebellum. Briefly, the cerebellar cells were cultured in the $25 \mathrm{ml}$ noncoated flask. On the next day, nonadherent cells were washed away, and adherent cells were cultured further. After cells were confluent, cells were removed with $1.0 \%$ trypsin-EDTA in HBSS and replated on noncoated flask. The cells obtained by this method were confirmed to consist of glia using anti-GFAP antibody (Santa Cruz Biotechnology, Santa Cruz, CA). Glial cells were mixed with cerebellar cells at a ratio of $3: 1$, and the mixed cells were spotted on plastic coverslips. After $12 \mathrm{~h}$, serum-free medium was added to make final serum concentration to be $1.0 \%$.

Immunoblotting. For Western blotting of granule cells, cerebellar cells taken from P7 WT or $\mathrm{IP}_{3} \mathrm{R} 1 \mathrm{KO}$ mice were cultured in the media (final, $1.0 \%$ serum $)$ containing $20 \mu \mathrm{M} \mathrm{AraC}\left(50 \mu \mathrm{l}\right.$ of $7 \times 10^{6}$ cells $\left./ \mathrm{ml}\right)$ for 5-6 d. In this condition, no Purkinje cells and glial cells survived. Cells were lysed with $150 \mu \mathrm{l}$ of sample buffer, and the cell lysates were boiled and separated by $7.5 \%$ SDS-PAGE and transferred to a polyvinyldene difluoride membrane. The membrane was treated with the blocking solution (0.05\% Tween 20/PBS) containing 5.0\% skim milk and probed with the indicated primary antibodies. The antibodies were used at the following concentrations: rabbit polyclonal anti-mGluR5 antibody $(1.0 \mu \mathrm{g} / \mathrm{ml}$; Upstate Biotechnology, Lake Placid, NY), mouse monoclonal anticalreticulin antibody $(1.0 \mu \mathrm{g} / \mathrm{ml}$; Affinity BioReagents, Golden, CO), mouse monoclonal anti- $\beta$-actin antibody $(1.0 \mu \mathrm{g} / \mathrm{ml}$; Sigma), rabbit polyclonal anti-pan-IP ${ }_{3} \mathrm{R}$ antibody (Hattori et al., 2004) $(\times 200)$, and rabbit polyclonal anti-IP ${ }_{3} \mathrm{R} 1$ antibody $(1.0 \mu \mathrm{g} / \mathrm{ml})$. After incubation with horseradish peroxidase-labeled secondary antibodies (GE Healthcare, Arlington Heights, IL), the immobilized specific antigen was visualized with ECL plus detection kit (GE Healthcare).

Immunocytochemistry. Cultured cells were washed with PBS and fixed with $4.0 \%$ paraformaldehyde in PBS for $15 \mathrm{~min}$ at room temperature (RT). After being washed with PBS, cells were permeabilized with $0.2 \%$ Triton in PBS for 10 min at RT and blocked with 3.0\% skim milk in PBS for $60 \mathrm{~min}$ at RT. The coverslips were incubated with primary antibodies for $2 \mathrm{~h}$ at RT or overnight at $4^{\circ} \mathrm{C}$. After being washed with PBS three times for a total of $15 \mathrm{~min}$, the coverslips were incubated with fluorescenceconjugated secondary antibodies (Alexa 488 or Alexa 596) (Invitrogen, Eugene, OR) for $60 \mathrm{~min}$ at RT. After being washed three times with PBS for $15 \mathrm{~min}$, the coverslips were mounted with Vectashield (Vector Laboratories, Burlingame, CA) and observed under an Olympus BX50 microscope (Olympus, Tokyo, Japan). Antibodies used were as follows: rat anti-IP ${ }_{3}$ R1 monoclonal antibody (18A10) (Maeda et al., 1988), mouse anticalbindin monoclonal antibody (1:400; Swant, Bellinzona, Switzerland), rabbit anti-NSE (neuron-specific enolase) polyclonal antibodies (1:200; Polysciences, Warrington, PA), and mouse anti-GFAP monoclonal antibody $(1.0 \mu \mathrm{g} / \mathrm{ml}$; Santa Cruz Biotechnology).

To measure maximum length of a primary dendrite, numbers of branch points on the primary dendrite, and dendritic area, images were stored and analyzed using IPLab (Scanalytics, Fairfax, VA) or a custommade software (TI Workbench, written by T.I.). Branch points were counted along a longest dendrite of each Purkinje cell. Dendritic area was measured by connecting the tips of dendrites including soma with straight line.

$\mathrm{Ca}^{2+}$ imaging. Cerebellar cells plated on poly-L-lysine-coated plastic disk were placed in a $3.5 \mathrm{~cm}$ glass-bottom dish (Matsunami, Tokyo, Japan) and loaded with $5.0 \mu \mathrm{M}$ fura-2 AM (Dojin Chemical, Kumamoto, Japan) for $30 \mathrm{~min}$ at room temperature in HEPES-buffered salt solution (HBSS) (in mM): $115 \mathrm{NaCl}, 5.4 \mathrm{KCl}, 1 \mathrm{MgCl}_{2}, 2 \mathrm{CaCl}_{2}, 20$ HEPES, 10 glucose, $\mathrm{pH}$ 7.42. Fura-2 fluorescence images were analyzed using an inverted microscope (IX70; Olympus) and TI workbench with excitation filters at $340 \pm 10$ and $380 \pm 10 \mathrm{~nm}$, a beam splitter at $400 \mathrm{~nm}$, and a bandpass emission filter at 510-550 nm. HBSS was used for the recording solution unless otherwise mentioned.

Reverse transcription-PCR. Cerebellar granule cells $\left(3.5 \times 10^{5}\right)$ from P7 WT or $\mathrm{IP}_{3} \mathrm{R} 1 \mathrm{KO}$ mice in 12-well dishes cultured for $6 \mathrm{~d}$ in the presence of $20 \mu \mathrm{M}$ AraC were incubated with $1.0 \mu \mathrm{M}$ TTX for $2 \mathrm{~h}$ to reduce basal neuronal activity. Then, the neurons were stimulated with $50 \mu \mathrm{M}(R S)$ 3,5-dihydroxyphenylglycine (DHPG) and $10 \mu \mathrm{M}$ AMPA. After $4 \mathrm{~h}$, the neurons were washed with PBS once and dissolved in $1.0 \mathrm{ml}$ of Trizol reagent (Invitrogen), and total RNA was extracted according to the instructions of the manufacturer. First-strand cDNA was produced from the total RNA using reverse transcriptase Superscript II (Invitrogen) and oligonucleotide (dT) primers. The cDNAs were amplified with specific primers: BDNF, sense 5'-TACTTCGGTTGCATGAAGGCGGCG-3', antisense 5' -TCCAAAGGCACTTGACTGCTGAGC-3'; glyceraldehyde3-phosphate dehydrogenase (GAPDH), sense 5'-ATGGTGAAGGTCGGTGTGAACCG-3', antisense 5'-AAACATGGGGGCATCGGCAGAA- $3^{\prime}$. After an initial cycle of $2 \mathrm{~min}$ at $94^{\circ} \mathrm{C}$, the reaction was cycled for $30 \mathrm{~s}$ at $94^{\circ} \mathrm{C}, 30 \mathrm{~s}$ at $55^{\circ} \mathrm{C}$, and $30 \mathrm{~s}$ at $72^{\circ} \mathrm{C}, 25$ times for GAPDH and 35 times for BDNF. For analysis, PCR products were separated by electrophoresis in $1.5 \%$ agarose gel and stained with ethidium bromide, and the band intensities were quantified with TI workbench. The expression level of GAPDH mRNA was used as an internal control.

Visualizing Purkinje cell shape in acute brain slices. Cerebellar slices (250 $\mu \mathrm{m}$ thick) were prepared according to a standard method (Kuruma et al., 2003) using P17-P20 WT and $\mathrm{IP}_{3} \mathrm{R} 1 \mathrm{KO}$ mice. Purkinje cells in the slices were patch clamped at the soma with internal solution containing $500 \mu \mathrm{m}$ fluorescein (Sigma). After waiting $15 \mathrm{~min}$ for the dye perfusion into the dendrite, the shape of single Purkinje cells was recorded with a two-photon confocal microscope with a $60 \times$ water immersion lens (numerical aperture, 0.90; Olympus). Consecutive 50-70 focal planes separated by $1 \mu \mathrm{m}$ were taken, and two-dimensional images of Purkinje cells were reconstructed by picking brightest pixel along each $z$-axis after correcting tilts of the dendritic plane by fitting to a horizontal plane in the threedimensional space. Data analysis was performed with TI Workbench.

Ultrastructure study. Anesthetized mice were intracardially fixed with $2.0 \%$ paraformaldehyde and $2.5 \%$ glutaraldehyde in $0.1 \mathrm{~m}$ phosphate buffer. Brain slices $(300 \mu \mathrm{m})$ prepared with a microslicer were postfixed in $1.0 \%$ osmium tetroxide, dehydrated, infiltrated with QY2, and then embedded in Araldite. Ultrathin sections were cut with an ultramic- 
A
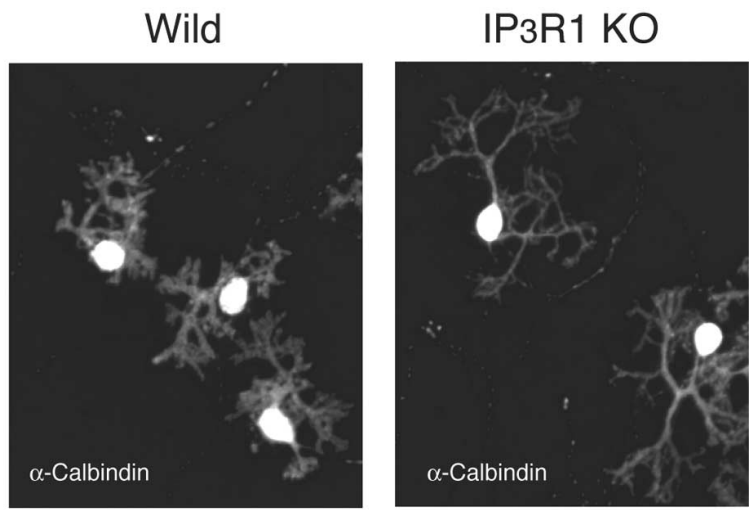

B

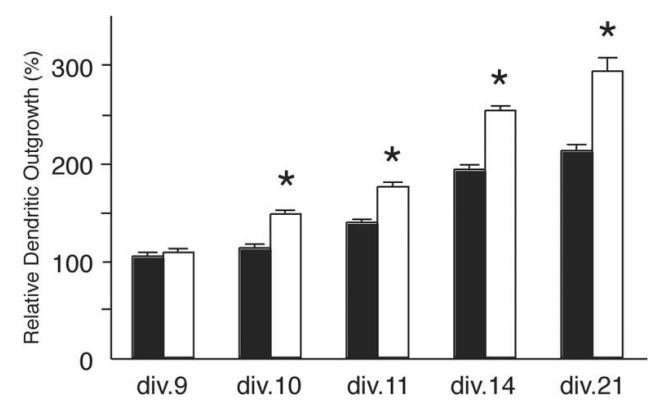

Figure 1. Abnormal dendritic outgrowth of cultured Purkinje cells from $\mathbb{P}_{3} \mathrm{R} 1 \mathrm{~K} 0$ mice. $\boldsymbol{A}$, Morphology of WT and $\mathbb{P}_{3} \mathrm{R} 1 \mathrm{~K} 0$ Purkinje cells stained with anti-calbindin antibody. $\boldsymbol{B}$, Time course of the dendritic outgrowth by Purkinje cells from WT and IP ${ }_{3} \mathrm{R} 1 \mathrm{KO}$ mice. Data expressed have been normalized to the primary dendrite length of wild-type Purkinje cells at 9 div. div.9: WT, $100 \pm 3.5(n=139), I_{3} R 1$ K0, $103.4 \pm 3.8(n=130)$; div.10: WT, $108.2 \pm 3.4(n=$ 139), IP ${ }_{3} R 1 K 0,141.6 \pm 3.7(n=116)$; div.11:WT, $133.1 \pm 3.5(n=129), I_{3} R 1$ K0, $168.5 \pm$ $4.6(n=104)$; div.14: WT, $185.3 \pm 4.9(n=96), \mathrm{IP}_{3} \mathrm{R} 1 \mathrm{~K} 0,243.0 \pm 4.4(n=96)$; div.21: WT, $204.2 \pm 5.9(n=90), I_{3} R 1$ K0, $282.1 \pm 13.5(n=55)$. $n$, Number of Purkinje cells used for analysis. All data are presented as mean \pm SEM. ${ }^{*} p<0.001$.

rotome, stained with uranyl acetate and lead citrate, and observed under a LEO912AB transmission electron microscope (Zeiss, Oberkochen, Germany) at $80 \mathrm{kV}$.

Statistical analysis. All data were shown as means \pm SEM (Student's $t$ test; $p<0.05$ was considered to be significant).

\section{Results}

\section{Cultured Purkinje cells from $\mathrm{IP}_{3} \mathrm{R} 1 \mathrm{KO}$ mice show abnormal} dendritic outgrowth

We removed cerebellar cells from P1-P2 WT and $\mathrm{IP}_{3} \mathrm{R} 1 \mathrm{KO}$ mice, cultured them for $14 \mathrm{~d}$, and immunostained them with anticalbindin antibody to visualize the dendritic morphology of the Purkinje cells. Interestingly, as shown in Figure $1 A$, the Purkinje cells from the $\mathrm{IP}_{3} \mathrm{R} 1 \mathrm{KO}$ mice showed abnormal dendritic outgrowth when compared with Purkinje cells from WT mice. To quantify the differences, we measured various parameters of the dendritic morphology of Purkinje cells. The maximal length of the primary dendrite of $\mathrm{IP}_{3} \mathrm{R} 1 \mathrm{KO}$ Purkinje cells was 1.4 -fold longer than that of the WT Purkinje cells [WT, 71.7 $\pm 1.8 \mu \mathrm{m}$ $(n=32) ; \mathrm{IP}_{3} \mathrm{R} 1 \mathrm{KO}, 101.6 \pm 2.0 \mu \mathrm{m}(n=26) ; n$, total number of Purkinje cells examined; $p<0.001$ ]. Dendritic area, defined as the area surrounded by straight lines connecting the ends of all terminal dendritic tips of a single Purkinje cell, was $4.8 \pm 0.2$ $\left(\times 10^{3} \mu \mathrm{m}^{2}\right)(n=35)$ for the WT Purkinje cells and $10.4 \pm 0.6$ $\left(\times 10^{3} \mu \mathrm{m}^{2}\right)(n=23)$ for $\mathrm{IP}_{3} \mathrm{R} 1 \mathrm{KO}$ Purkinje cells $(p<0.001)$. The primary dendrites of the $\mathrm{IP}_{3} \mathrm{R} 1 \mathrm{KO}$ Purkinje cells tended to be slightly thinner than those of the WT Purkinje cells [WT, 4.2 \pm $\left.0.2 \mu \mathrm{m}(n=44) ; \mathrm{IP}_{3} \mathrm{R} 1 \mathrm{KO}, 2.7 \pm 0.2 \mu \mathrm{m}(n=34) ; p<0.001\right]$.
There were fewer branch points on the primary dendrite of the $\mathrm{IP}_{3} \mathrm{R} 1 \mathrm{KO}$ Purkinje cells than of the WT Purkinje cells [WT, $6.5 \pm$ $\left.0.3(n=32) ; \mathrm{IP}_{3} \mathrm{R} 1 \mathrm{KO}, 4.6 \pm 0.2(n=26) ; p<0.001\right]$, resulting in the longer intervals between adjacent branch points in $\mathrm{IP}_{3} \mathrm{R} 1 \mathrm{KO}$ Purkinje cells [WT, $11.3 \pm 0.5 \mu \mathrm{m}(n=31) ; \mathrm{IP}_{3} \mathrm{R} 1 \mathrm{KO}$, $23.9 \pm 1.6 \mu \mathrm{m}(n=25) ; p<0.001]$. This abnormal dendritic morphology was specific to the $\mathrm{IP}_{3} \mathrm{R} 1 \mathrm{KO}$ mice, because it was not seen in cultured Purkinje cells from $\mathrm{IP}_{3} \mathrm{R} 2 / 3$ double $\mathrm{KO}$ mice (Futatsugi et al., 2005). The maximal length of the primary dendrites of $\mathrm{IP}_{3} \mathrm{R} 2 / 3$ double $\mathrm{KO}$ Purkinje cells was slightly less than in WT Purkinje cells, but the difference was not statistically significant (data not shown).

Because the density of granule cells surrounding Purkinje cells in culture is well known to profoundly affect the dendritic morphology of the Purkinje cells through glutamate and/or neurotrophic factors (Schilling et al., 1991; Hirai and Launey, 2000), a difference in density between the surviving granule cells in the WT and $\mathrm{IP}_{3} \mathrm{R} 1 \mathrm{KO}$ cerebellar cultures might have explained the abnormal dendritic morphology of $\mathrm{IP}_{3} \mathrm{R} 1 \mathrm{KO}$ Purkinje cells, but immunostaining with anti-NSE (neuron-specific enolase) antibody revealed no significant difference in granule cell density between the two groups (WT, $3.22 \pm 0.21 \times 10^{7} \mathrm{cells} / \mu \mathrm{m}^{2}, n=$ 14; $\mathrm{IP}_{3} \mathrm{R} 1 \mathrm{KO}, 2.99 \pm 0.16 \times 10^{7}$ cells $\left./ \mu \mathrm{m}^{2}, n=15\right)$.

Next, to examine the time course of the morphological change in the dendrites of WT and $\mathrm{IP}_{3} \mathrm{R} 1 \mathrm{KO}$ Purkinje cells, we measured the maximal length of the primary dendrite of Purkinje cells cultured for various periods. The length of the primary dendrite of the Purkinje cells in the two groups was not statistically different until 9 div (Fig. $1 B$ ). At 10 div, the $\mathrm{IP}_{3} \mathrm{R} 1 \mathrm{KO}$ Purkinje cells had longer primary dendrites than the WT Purkinje cells, and the difference became more evident at 11,12, and 14 div. A difference in morphology between the WT and $\mathrm{IP}_{3} \mathrm{R} 1 \mathrm{KO}$ Purkinje cells was also observed at 21 div, when the Purkinje cell dendrites were almost mature.

\section{$\mathrm{IP}_{3} \mathrm{R} 1$ in Purkinje cells is not responsible for the abnormal dendritic outgrowth of Purkinje cells}

The notion that $\mathrm{IP}_{3} \mathrm{R} 1$ is dominantly expressed in Purkinje cells (Furuichi et al., 1989, 1993) easily led us to speculate that the $\mathrm{IP}_{3} \mathrm{R} 1$ expressed in Purkinje cells contributes to the regulation of the dendritic outgrowth of Purkinje cells. However, there was another possibility that the $\mathrm{IP}_{3} \mathrm{R} 1$ expressed in other cells (e.g., granule cells and glial cells) rather than in the Purkinje cells contributed to it. To identify the source of the $\mathrm{IP}_{3} \mathrm{R} 1$ that regulated the outgrowth of Purkinje cell dendrites, we prepared mixed culture of WT and $\mathrm{IP}_{3} \mathrm{R} 1 \mathrm{KO}$ cerebellar cells (chimera culture) and examined the dendritic morphology of the Purkinje cells. If the intrinsic $\mathrm{IP}_{3} \mathrm{R} 1$ in the Purkinje cells controlled the dendritic morphology of the Purkinje cells, the dendritic morphology of the $\mathrm{IP}_{3} \mathrm{R} 1 \mathrm{KO}$ Purkinje cells should have remained abnormal in the chimera culture. Immunostaining of Purkinje cells with both anti-IP ${ }_{3} \mathrm{R} 1$ antibody and anti-calbindin antibody enabled us to easily distinguish between $\mathrm{WT}$ and $\mathrm{IP}_{3} \mathrm{R} 1 \mathrm{KO}$ Purkinje cells, but as shown in Figure 2, the dendritic morphology of the $\mathrm{IP}_{3} \mathrm{R} 1 \mathrm{KO}$ Purkinje cells in the chimera culture became indistinguishable from that of the WT Purkinje cells [relative dendrite length of WT and $\mathrm{IP}_{3} \mathrm{R} 1 \mathrm{KO}$ Purkinje cells: WT, $100 \pm 3.0 \%(n=48)$; $\mathrm{IP}_{3} \mathrm{R} 1 \mathrm{KO}, 101.1 \pm 2.4 \%(n=48)$; n.s.]. This finding, showing that the abnormal dendritic shape of $\mathrm{IP}_{3} \mathrm{R} 1 \mathrm{KO}$ Purkinje cells was rescued by culturing with WT cerebellar cells, suggests that the dendritic outgrowth of Purkinje cells is regulated by a factor(s) provided by other cerebellar cells, the expression of which is $\mathrm{IP}_{3} \mathrm{R} 1$ dependent. 


\section{A

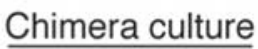

P1 cerebellar cells (Wild)
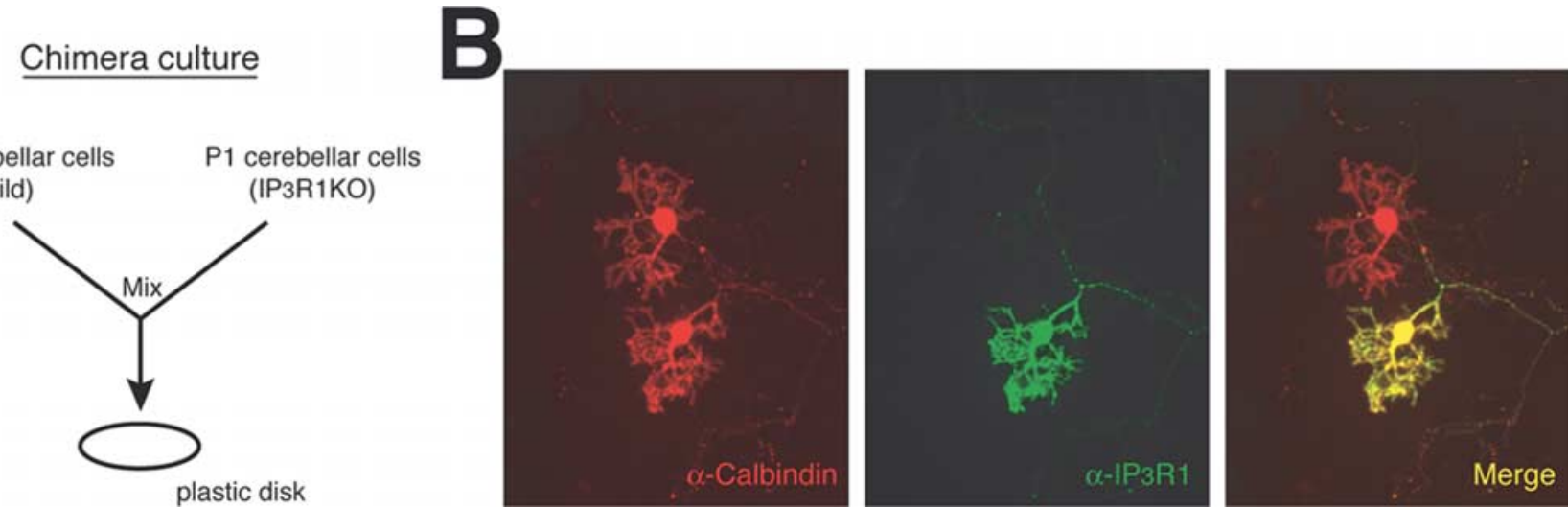

Figure 2. Morphology of $I P_{3} R 1$ KO Purkinje cells in mixed culture. $A, B$, Cerebellar cells from IP ${ }_{3} R 1$ K0 mice and WT mice were mixed and cultured for $14 \mathrm{~d}$ and then fixed and stained for anti-IP $\mathrm{R} 1$ antibody (green) and anti-calbindin antibody (red), respectively. Note that when $\mathrm{P}_{3} \mathrm{R} 1 \mathrm{~K} 0$ cerebellar cells were mix-cultured with WT cerebellar cells, the dendritic outgrowth of the $\mathrm{P}_{3} \mathrm{R} 1 \mathrm{KO}$ Purkinje cells became similar to that of the WT Purkinje cells.

A

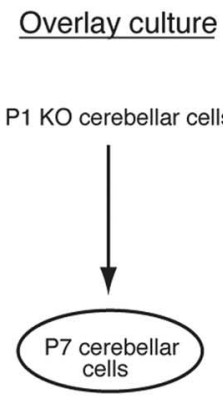

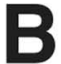

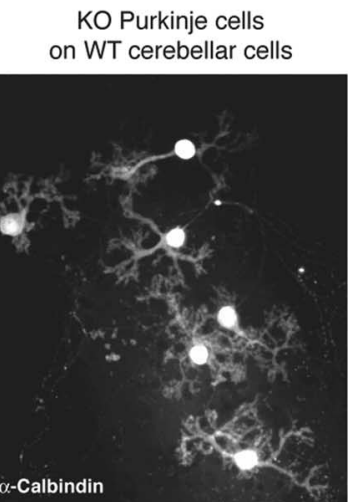

KO Purkinje cells on $\mathrm{KO}$ cerebellar cells

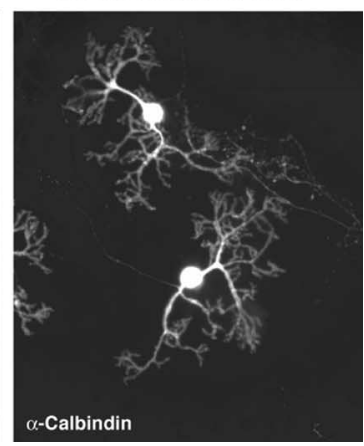

Figure 3. Morphology of $\mathrm{IP}_{3} \mathrm{R} 1 \mathrm{KO}$ Purkinje cells in overlay culture. $A$, Schematic illustration of overlay culture. Cerebellar cells from WT or IP $\mathrm{R} 1 \mathrm{KO}$ P7 mice were first plated on a plastic disk. Thenext day, cerebellar neurons from P1 IP $\mathrm{R} 1 \mathrm{~K} 0$ mice were plated on the previously cultured cerebellar cells from the P7 mice. The cells were cultured for an additional $14 \mathrm{~d}$, fixed, and stained with anti-calbindin antibody. $\boldsymbol{B}$, The dendritic length of $I P_{3} R 1$ KO Purkinje cells was shorter when cultured on P7 WT cerebellar cells than when grown on P7 IP $\mathrm{P} 1 \mathrm{KO}$ cerebellar cells. Relative dendritic length of Purkinje cells is shown. IP ${ }_{3}$ R1 KO Purkinje cells cultured on P7 WT cerebellar cells, $100 \pm 3.9 \%$ $(n=28) ; \mathbb{P}_{3} R 1$ K0 Purkinje cells cultured on $\mathrm{P} 7 \mathrm{IP}_{3} \mathrm{R} 1 \mathrm{~K} 0$ cerebellar cells, $115.1 \pm 3.8 \%(n=21)$. The difference between the primary dendrite length of $\mathrm{IP}_{3} \mathrm{R} 1 \mathrm{~K} 0$ Purkinje cells cultured on WT and $\mathrm{IP}_{3} \mathrm{R} 1 \mathrm{~K} 0$ cerebellar cells was significant: $p<0.01$.

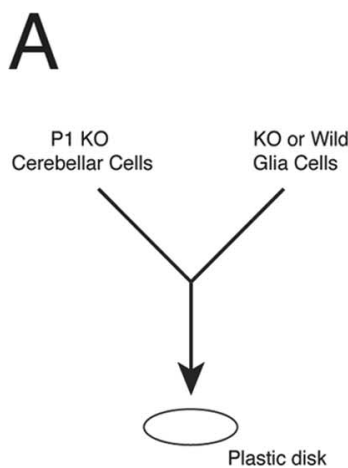

Plastic disk

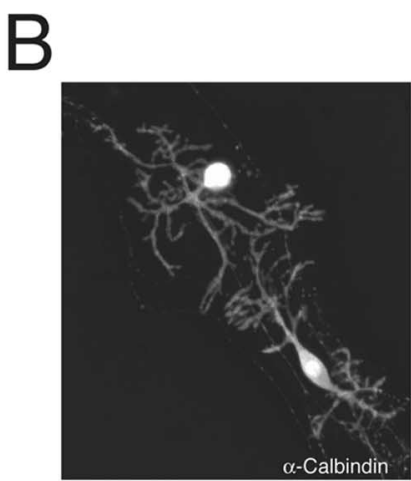

KO+Wild Glia

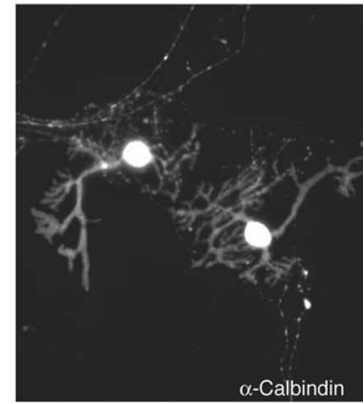

KO+KO Glia

Figure 4. $\quad \mathrm{IP}_{3} \mathrm{R} 1$ in glial cells was not involved in regulation of the dendritic outgrowth of Purkinje cells. $A$, Schematicillustration of the culture method. P1 cerebellar cells from IP ${ }_{3} R 1$ K0 mice were mixed with WT or IP $R 1$ K0 glial cells and cultured for $14 \mathrm{~d}$. Purkinje cells were stained with anti-calbindin antibodies. $\boldsymbol{B}$, Morphology of the dendritic outgrowth of $\mathbb{I}_{3} \mathrm{R} 1 \mathrm{KO}$ Purkinje cells that were mix-cultured with WT or IP $R 1$ K0 cerebellar glial cells.

To confirm the contribution of $\mathrm{IP}_{3} \mathrm{R} 1$ expressed by cells other than Purkinje cells to the dendritic outgrowth of Purkinje cells, we performed an overlay culture by first culturing WT or $\mathrm{IP}_{3} \mathrm{R} 1 \mathrm{KO}$ cerebellar cells taken from P7 mice and overlaying them with $\mathrm{IP}_{3} \mathrm{R} 1 \mathrm{KO}$ cerebellar cells taken from P1 IP ${ }_{3} \mathrm{R} 1 \mathrm{KO}$ mice $1 \mathrm{~d}$ later (Fig. $3 A$ ). Because Purkinje cells obtained from P7 mice cerebellum do not survive in culture, P7 cerebellar cultures do not contain any Purkinje cells. We confirmed the absence of Purkinje cells in cerebellar cultures from P7 mice by immunostaining with anticalbindin antibody (data not shown). As shown in Figure 3B, when we overlaid P1 $\mathrm{IP}_{3} \mathrm{R} 1 \mathrm{KO}$ cerebellar cells on P7 WT cerebellar cells, the dendritic outgrowth of the $\mathrm{IP}_{3} \mathrm{R} 1 \mathrm{KO}$ Purkinje cells was clearly suppressed, and their dendritic morphology was similar to that of WT Purkinje cells, whereas $\mathrm{IP}_{3} \mathrm{R} 1 \mathrm{KO}$ Purkinje cells grown on P7 $\mathrm{IP}_{3} \mathrm{R} 1 \mathrm{KO}$ cerebellar cells still showed abnormal dendritic outgrowth [relative dendritic length of Purkinje cells were: $\mathrm{IP}_{3} \mathrm{R} 1 \mathrm{KO}$ Purkinje cells cultured on P7 WT cerebellar cells, $100 \pm$ $3.9 \%(n=28)$; IP ${ }_{3} \mathrm{R} 1 \mathrm{KO}$ Purkinje cells cultured on P7 IP $\mathrm{IP}_{3} \mathrm{R} 1 \mathrm{KO}$ cerebellar cells, $115.1 \pm 3.8 \%(n=21) ; p<0.01]$. These results strongly support one of the possibilities described above (i.e., that $\mathrm{IP}_{3} \mathrm{R} 1$ expressed in other cell types, not in Purkinje cells, regulates the dendritic outgrowth of Purkinje cells).

To investigate whether deletion of the $\mathrm{IP}_{3} \mathrm{R} 1$ gene in glial cells contributed to the abnormal dendritic outgrowth of Purkinje cells in $\mathrm{IP}_{3} \mathrm{R} 1 \mathrm{KO}$ mice, we prepared glial cell culture from $\mathrm{P} 1 \mathrm{WT}$ and $\mathrm{IP}_{3} \mathrm{R} 1 \mathrm{KO}$ cerebella. The morphology of the WT and $\mathrm{IP}_{3} \mathrm{R} 1 \mathrm{KO}$ glial cells was indistinguishable, and the proliferation rates of the two groups were not significantly different (data not shown). We mixed WT or IP ${ }_{3} \mathrm{R} 1$ $\mathrm{KO}$ glial cells with $\mathrm{P} 1 \mathrm{IP}_{3} \mathrm{R} 1 \mathrm{KO}$ cerebellar cells (in the ratio of 3:1) and cultured them

for $14 \mathrm{~d}$, but there was no significant morphological difference between $\mathrm{IP}_{3} \mathrm{R} 1 \mathrm{KO}$ Purkinje cells cultured with $\mathrm{WT}$ and $\mathrm{IP}_{3} \mathrm{R} 1 \mathrm{KO}$ glial cells (Fig. 4), suggesting that the $\mathrm{IP}_{3} \mathrm{R} 1$ expressed in glial cells, if any, does not contribute to the 


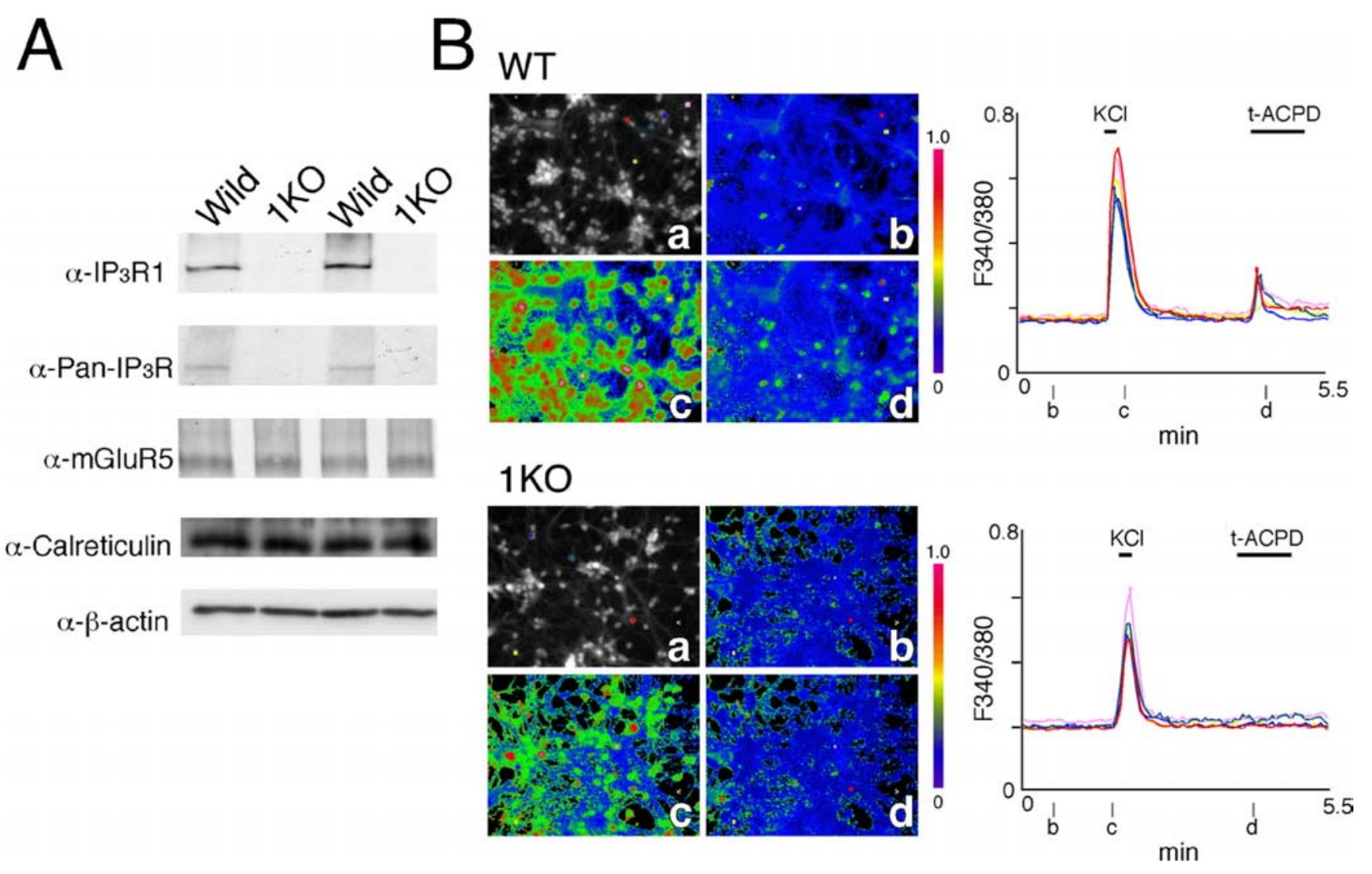

Figure 5. Abnormal $\mathrm{Ca}^{2+}$ signaling of $I \mathrm{P}_{3} \mathrm{R} 1 \mathrm{KO}$ cerebellar granule cells in response to mGluR stimulation. $A$, Expression level of various proteins in WT and IP $\mathrm{P}_{3} \mathrm{R} 1 \mathrm{KO}(1 \mathrm{KO})$ cerebellar granule cells. Lysates of cerebellar neurons were probed with the antibodies indicated. $B$, $\mathrm{Ca}^{2+}$ signaling in WT and IP ${ }_{3} \mathrm{R} 1 \mathrm{KO}$ cerebellar granule cells. After depolarization with $30 \mathrm{~mm} \mathrm{KCl}$ to fill the $\mathrm{Ca}^{2+}$ stores, the cells were stimulated with $100 \mu$ m trans-ACPD, an agonist for group 1 mGluRs. $\boldsymbol{a}$, Fura-2 images of cerebellar granule cells. $\boldsymbol{b}-\boldsymbol{d}$, The ratio image of $\mathrm{Ca}^{2+}$ concentration at the times shown in the right panel.

dendritic morphology of Purkinje cells [relative dendrite length of Purkinje cells: $\mathrm{IP}_{3} \mathrm{R} 1 \mathrm{KO}$ Purkinje cells plus WT glial cells, $100 \pm 4.1 \%(n=43) ; \mathrm{IP}_{3} \mathrm{R} 1 \mathrm{KO}$ Purkinje cells plus $\mathrm{IP}_{3} \mathrm{R} 1 \mathrm{KO}$ glial cells, $95 \pm 3.4 \%(n=78)$; n.s. $]$.

\section{Abnormal $\mathrm{Ca}^{2+}$ signaling in $\mathrm{IP}_{3} \mathrm{R} 1 \mathrm{KO}$ cerebellar granule cells in response to $\mathrm{mGluR}$ stimulation}

We next investigated the possibility that the $\mathrm{IP}_{3} \mathrm{R} 1$ expressed in cerebellar granule cells contributes to the dendritic outgrowth of

Purkinje cells. First, we investigated the expression of $\mathrm{IP}_{3} \mathrm{R} 1$ in cultured cerebellar granule cells by using cerebellar cell cultures taken from P7 mice and maintained for 5-6 d in vitro, under which conditions no Purkinje cells or glial cells survive. We detected $\mathrm{IP}_{3} \mathrm{R} 1$ expression in WT cerebellar granule cells with anti$\mathrm{IP}_{3} \mathrm{R} 1$ antibody (Fig. 5A), but no signal was detected in $\mathrm{IP}_{3} \mathrm{R} 1 \mathrm{KO}$ cerebellar granule cells. Importantly, $\mathrm{IP}_{3} \mathrm{R} 1$ was the dominant $\mathrm{IP}_{3} \mathrm{R}$ subtype in the cerebellar granule cells, because no signal was detected in the $\mathrm{IP}_{3} \mathrm{R} 1 \mathrm{KO}$ cerebellar granule cells with anti-Pan $\mathrm{IP}_{3} \mathrm{R}$ antibody, which recognizes all three types of $\mathrm{IP}_{3} \mathrm{Rs}$ equally (Hattori et al., 2004). To determine whether $\mathrm{IP}_{3} \mathrm{R} 1$ actually functions in granule cells, we stimulated granule cells with trans- $( \pm)-$ 1-amino-1,3-cyclopentanedicarboxylic acid (ACPD), an agonist for group 1 metabotropic glutamate receptors that are linked to the phospholipase $\mathrm{C}$ (PLC)- $\mathrm{IP}_{3}$ production pathway, and measured $\mathrm{Ca}^{2+}$ changes. To maximize the $\mathrm{IP}_{3}$-induced $\mathrm{Ca}^{2+}$ release, we exposed the cells to high $\mathrm{K}^{+}$before mGluR stimulation (del
Rio et al., 1994). As shown in Figure 5B, a $\mathrm{Ca}^{2+}$ transient was observed in WT cerebellar granule cells in response to transACPD (top panel), but no $\mathrm{Ca}^{2+}$ transient, only a slight increase in basal $\mathrm{Ca}^{2+}$ level, was observed in the $\mathrm{IP}_{3} \mathrm{R} 1 \mathrm{KO}$ cerebellar granule cells. Approximately 50\% of the WT cerebellar granule cells responded to mGluR stimulation, whereas only $7.0 \%$ of $\mathrm{IP}_{3} \mathrm{R} 1 \mathrm{KO}$ cells did [WT, $45.1 \pm 6.3 \%(n=601) ; 1 \mathrm{KO}, 7.3 \pm 2.2 \%(n=$ 567), $n$, number of cells examined; $p<0.001$ ]. Together, these results demonstrated that $\mathrm{IP}_{3} \mathrm{R} 1$ is expressed in cerebellar granule cells and plays a major role in $\mathrm{Ca}^{2+}$ signaling after mGluR stimulation.

Reduced BDNF expression in $\mathrm{IP}_{3} \mathrm{R} 1 \mathrm{KO}$ granule cells in response to AMPAR and mGluR stimulation

Because BDNF is a neurotropic factor and one of the major factors regulating dendritic morphology (Jan and Jan, 2003), we tested its effect on the abnormal dendritic morphology of $\mathrm{IP}_{3} \mathrm{R} 1$ KO Purkinje cells by adding BDNF to the culture. Interestingly, BDNF rescued the abnormal morphology (Fig. 6A, $B$ ), suggesting possible involvement of BDNF in the dendritic shaping of Purkinje cells.

It is known that BDNF production by AMPAR stimulation is further augmented by costimulation with mGluRs (Baird et al., 1991; Yuzaki et al., 1994). In addition, stimulation of AMPAR increases the cytosolic $\mathrm{Ca}^{2+}$ concentration via depolarizationinduced $\mathrm{Ca}^{2+}$ entry, which facilitates the activation of $\mathrm{Ca}^{2+}$ - 


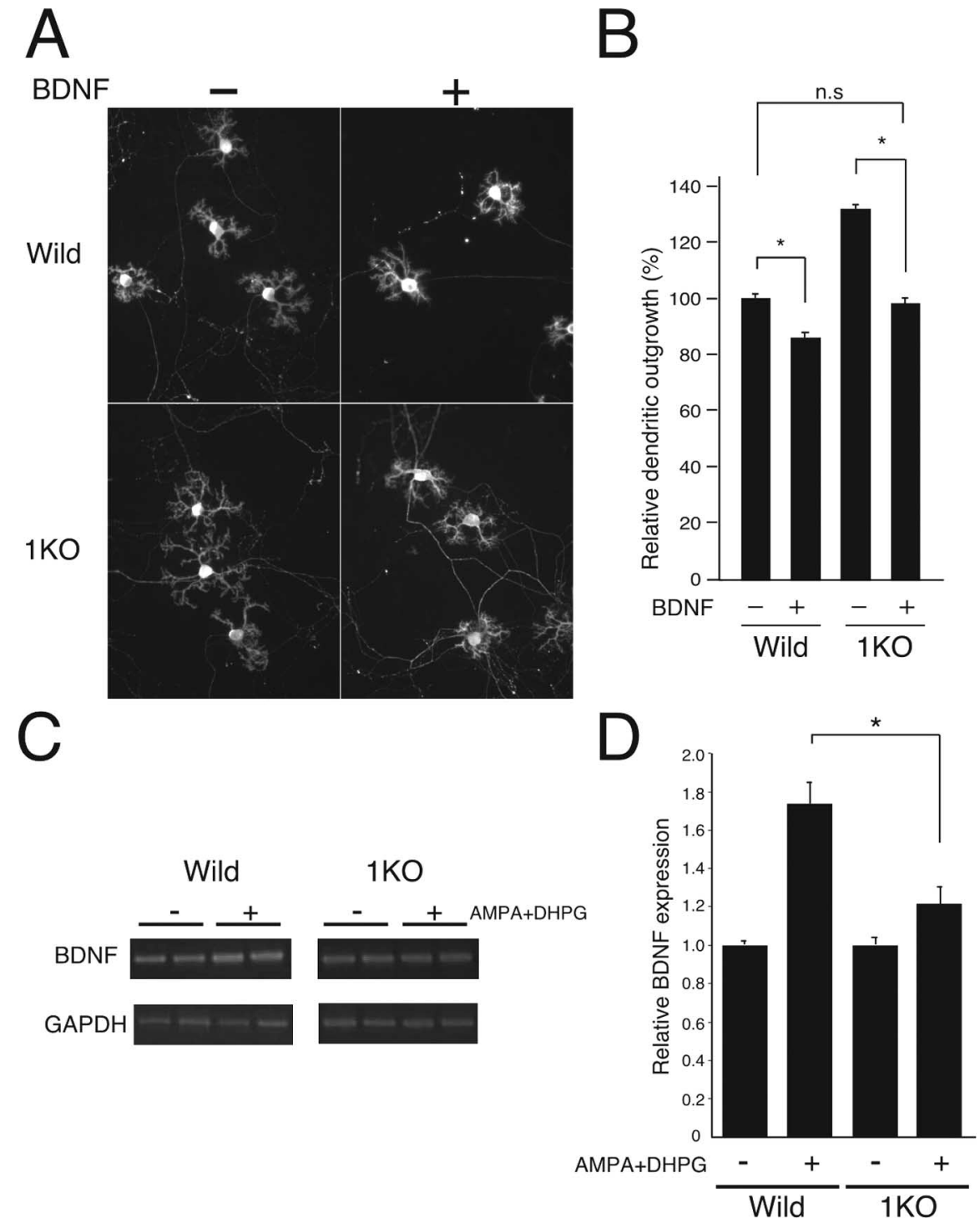

Figure 6. BDNF application rescued abnormal dendritic outgrowth of $I P_{3} R 1$ KO Purkinje cells. $A$, Effect of BDNF on the dendritic morphology of WT and IP ${ }_{3}$ R1 KO Purkinje cells. Cerebellar cells were exposed to BDNF (10 ng/ml) from 9 to 14 div for $5 \mathrm{~d}$, fixed, and stained with anti-calbindin antibody. $B$, Relative dendritic outgrowth of WT and IP ${ }_{3} R 1$ KO (1KO) Purkinje cells exposed to BDNF normalized by maximal dendritic length of WT Purkinje cells in the absence of BDNF. WT, $100 \pm 1.5(n=366)$; WT plus BDNF, $85.8 \pm 2.0(n=148) ; 1 K 0,131.6 \pm 1.6(n=248) ; 1 K 0$ plus BDNF, $98.0 \pm 2.0(n=166) . n$, Number of cells examined. ${ }^{*} p<$ 0.001. n.s., Not significant; $p=0.43$. $C, D$, Reduced BDNF expression by $I_{3} R 1$ KO cerebellar granule cells in response to AMPAR and mGluR stimulation. Cerebellar granule cells taken from P7 WT and IP $\mathrm{R} 1 \mathrm{KO}$ mice were cultured for $7 \mathrm{~d}$ and then stimulated with $10 \mu \mathrm{m}$ AMPA and $50 \mu \mathrm{m}$ DHPG. After $4 \mathrm{~h}$, RNAs were extracted from the cells and used for reverse transcription-PCR of BDNF and GAPDH. C, BDNF and GAPDH mRNA expression levels detected by reverse transcription-PCR. $\boldsymbol{D}$, Relative increase in BDNF mRNA after AMPAR and mGluR stimulation. Wild, $1.7 \pm 0.1(n=14) ; 1 \mathrm{KO}, 1.2 \pm 0.1(n=13) .{ }^{*} p<0.02$.

dependent proteins, PLC and $\mathrm{IP}_{3} \mathrm{R}$, that function under mGluR signal pathway (del Rio et al., 1994; Nash et al., 2004; Young et al., 2004). Therefore, we hypothesized that $\mathrm{IP}_{3} \mathrm{R} 1$ activity regulates the expression level of BDNF in cultured cerebellar cells after stimulation of AMPAR and mGluRs. As expected, we found that stimulation with AMPA and DHPG, agonists for the AMPAR and the group $1 \mathrm{mGluR}$, respectively, increased BDNF expression by 1.7 times in WT granule cells but much less in $\mathrm{IP}_{3} \mathrm{R} 1 \mathrm{KO}$ granule cells (1.2-fold) (Fig. 6C,D). Together, these results suggest the existence of a mechanism of $\mathrm{IP}_{3} \mathrm{R} 1$-mediated activity-dependent BDNF expression in cerebellar granule cells that regulates the dendritic shaping of Purkinje cells.

\section{Abnormal dendritic morphology of Purkinje cells and ultrastructure of PF- $\mathrm{PC}$ synapses in $\mathrm{IP}_{3} \mathrm{R} 1 \mathrm{KO}$ mice in vivo} Because BDNF deficiency led to abnormality of ultrastructure of PF-PC synapses and dendritic morphology of Purkinje cells in vivo (Carter et al., 2002), we finally examined the dendritic morphology of Purkinje cells and ultrastructure of PF-PC synapses in $\mathrm{IP}_{3} \mathrm{R} 1 \mathrm{KO}$ mice in vivo. As shown in Figure $7 A$, although overall PF-PC synaptogenesis appeared normal in the $\mathrm{IP}_{3} \mathrm{R} 1 \mathrm{KO}$ cerebella, significant extension of the length of postsynaptic density (PSD) was observed in the $\mathrm{IP}_{3} \mathrm{R} 1 \mathrm{KO}$ PF-PC synapses [WT, $0.24 \pm 0.01 \mu \mathrm{m}$ $(n=211) ; \mathrm{IP}_{3} \mathrm{R} 1 \mathrm{KO}, 0.33 \pm 0.01 \mu \mathrm{m}(n=$ $256) ; p<0.001 ; n$, number of synapses examined]. In addition, presynaptic enlargement and increase in vesicle number in axon terminals of cerebellar granule cells were apparent in $\mathrm{IP}_{3} \mathrm{R} 1 \mathrm{KO}$ cerebella, suggesting an alteration in the synaptic transmission efficacy of the PF-PC synapses in $\mathrm{IP}_{3} \mathrm{R} 1 \mathrm{KO}$ cerebella (Fig. $7 B$ ). We also examined the shape of the dendrites of individual Purkinje cells in acute cerebellar slices by injecting a fluorescent dye by the patch-clamp technique (see Materials and Methods). As shown in Figure $7 C$, whereas WT Purkinje cells extended their dendrites evenly throughout the dendritic area, the dendritic morphology of the $\mathrm{IP}_{3} \mathrm{R} 1 \mathrm{KO}$ Purkinje cells was clearly abnormal, with vacant areas lacking any dendritic structures in the dendritic arbor. To quantify the abnormality, we measured the density of branch points by counting them and measuring the dendritic area of the Purkinje cells. $\mathrm{IP}_{3} \mathrm{R} 1 \mathrm{KO}$ Purkinje cells had reduced branching point density [branch numbers per unit dendritic area: $\mathrm{WT}, 3.0 \pm 0.1(n=32) ; \mathrm{IP}_{3} \mathrm{R} 1 \mathrm{KO}, 2.3 \pm$ $\left.0.1(n=34)\left(\times 10^{3} \mathrm{n} / \mathrm{mm}^{2}\right) ; p<0.001\right]$, consistent with the observation in the culture study described above. In contrast, there was no significant difference in spine density and maximal length of the primary dendrite between WT and $\mathrm{IP}_{3} \mathrm{R} 1 \mathrm{KO}$ Purkinje cells in vivo (supplemental Fig. 1, available at www.jneurosci.org as supplemental material) (data not shown). The spatial limitations on dendritic outgrowth in the cerebellar cortex may explain the reason why maximal length of the primary dendrite of $\mathrm{IP}_{3} \mathrm{R} 1 \mathrm{KO}$ Purkinje cells was longer than that of WT cells in vitro (Fig. 1) but not in vivo. We also examined the number of inhibitory interneurons that innervate and affect the excitability of Purkinje cells, but there was no apparent difference in the immunoreactivity of GAD67, one of the marker of inhibitory interneurons, between WT and $\mathrm{IP}_{3} \mathrm{R} 1 \mathrm{KO}$ cerebella (supplemental Fig. 2, available at www.jneurosci.org as supplemental material). Together, these results suggested that $\mathrm{IP}_{3} \mathrm{R} 1$ plays an important role in shaping 


\section{A}
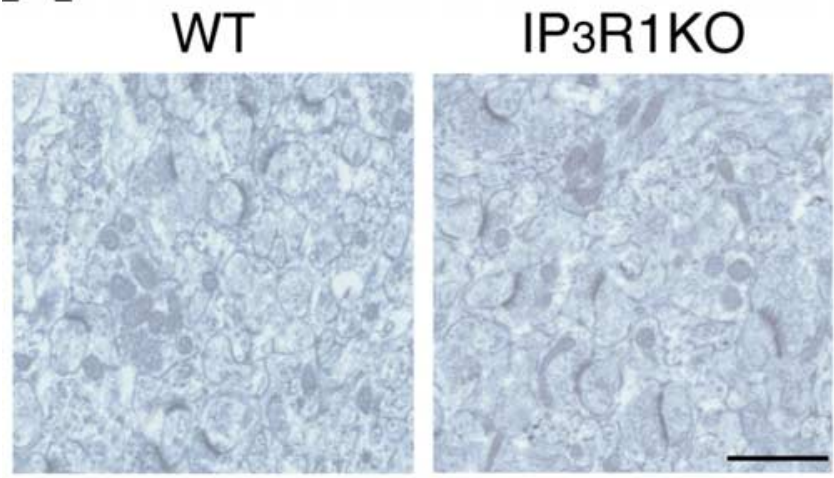

WT
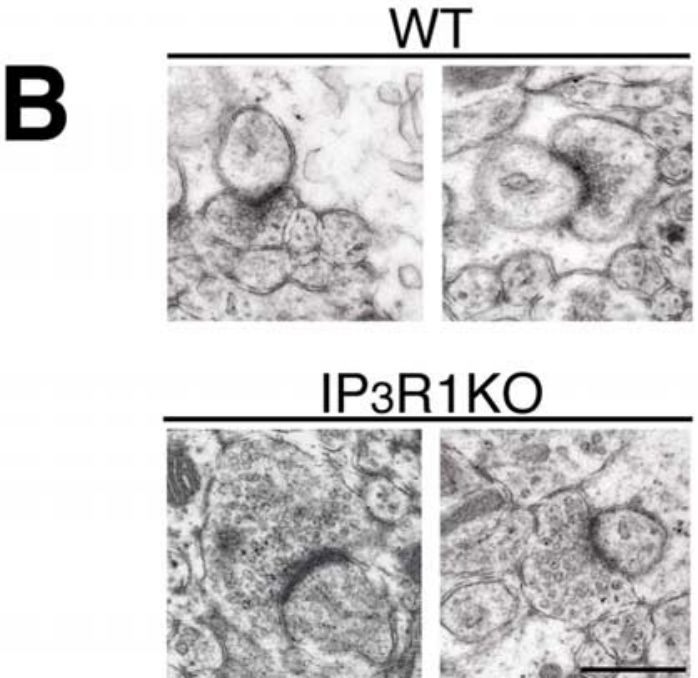

\section{IP3R1KO}

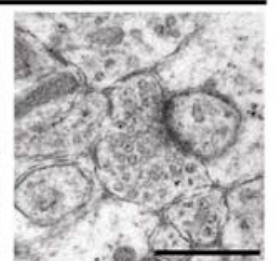

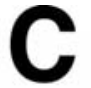

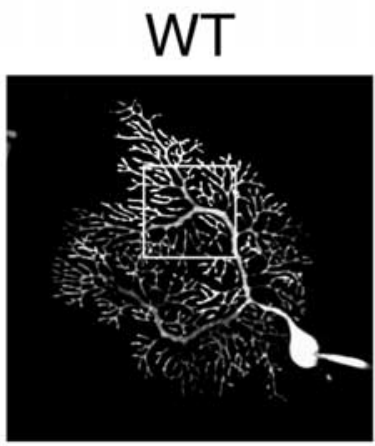

IP3R1KO
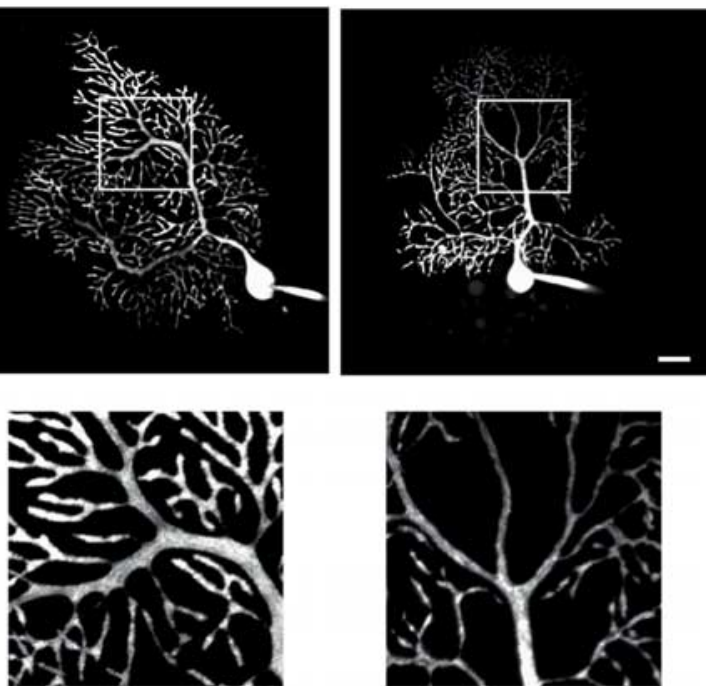

D

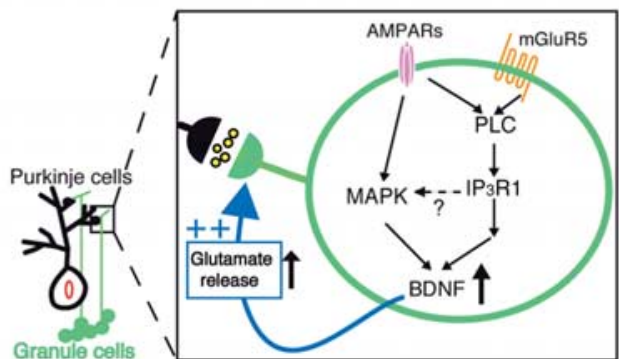

Figure 7. Abnormal dendritic morphology of $\mathrm{P}_{3} \mathrm{R} 1 \mathrm{KO}$ Purkinje cells in vivo. $\boldsymbol{A}$, Ultrastructure of the molecular layer of the cerebellum of WT and IP ${ }_{3} \mathrm{R} 1 \mathrm{~K} 0 \mathrm{mice}$. Scale bar, $1.0 \mu \mathrm{m}$. $\boldsymbol{B}$, Enlargement of presynaptic terminals and vesicle accumulation in PF-PC synapses in $I_{3} R 1$ K0 mice. Scale bar, $0.5 \mu \mathrm{m}$. C, Purkinje cells in acute cerebellar slices from WT and IP ${ }_{3} R 1 \mathrm{KO}$ mice $(\sim P 17-P 20)$ were loaded with intracellular solution containing fluorescein $(500 \mu \mathrm{m})$ by means of patch pipette in the whole-cell configuration. After 15 min, the dendritic morphology of Purkinje cells was visualized with a two-photon microscope. Typical images of the dendritic morphology of WT and IP $\mathrm{R} 1 \mathrm{KO}$ Purkinje cells reconstructed from image stack of serial focal planes are shown (top panels). The bottom panels show the magnification view images of the area indicated by squares in the top panels. Scale bar, $20 \mu \mathrm{m}$. $D$, A schematic model of the regulation of dendritic morphology of Purkinje cells by $\mathrm{IP}_{3} \mathrm{R} 1$ expressed in granule cells. The BDNF production in granule cells by AMPAR stimulation is augmented by costimulation of mGluR5 through IP ${ }_{3} R 1-$ mediated signaling. Then, the produced BDNF increases the probability of transmitter release from presynaptic terminals of granule cells in an autocrine manner, leading to the increase of excitability of Purkinje cells and the subsequent branching of Purkinje cell dendrites.

the dendritic morphology of Purkinje cells in vivo, possibly by changing PF-PC synaptic efficacy.

\section{Discussion}

In this study, we demonstrated abnormal dendritic outgrowth by cultured Purkinje cells from $\mathrm{IP}_{3} \mathrm{R} 1 \mathrm{KO}$ mice. Despite the very high level of expression of $\mathrm{IP}_{3} \mathrm{R} 1$ in Purkinje cells, the following

lines of evidence led us to conclude that the $\mathrm{IP}_{3} \mathrm{R} 1$ in cerebellar granule cells, not in Purkinje cells, contributes to regulation of the dendritic outgrowth of Purkinje cells. First, the dendritic morphology of WT and $\mathrm{IP}_{3} \mathrm{R} 1 \mathrm{KO}$ Purkinje cells was indistinguishable in the chimera culture when the surrounding cellular environment was same. Second, the dendritic morphology of $\mathrm{IP}_{3} \mathrm{R} 1 \mathrm{KO}$ Purkinje cells cultured on WT cerebellar cells tend to be similar to that of WT Purkinje cells. Third, of the three types of $\mathrm{IP}_{3} \mathrm{Rs}$, cultured cerebellar granule cells dominantly express $\mathrm{IP}_{3} \mathrm{R} 1$, and cerebellar granule cells lacking $\mathrm{IP}_{3} \mathrm{R} 1$ released less $\mathrm{Ca}^{2+}$ after mGluR stimulation. Fourth, the increase in BDNF production in response to mGluR stimulation and AMPAR stimulation was significantly reduced in $\mathrm{IP}_{3} \mathrm{R} 1 \mathrm{KO}$ cerebellar granule cells, and exogenous BDNF application rescued the abnormal morphology of $\mathrm{IP}_{3} \mathrm{R} 1 \mathrm{KO}$ Purkinje cells. Thus, our findings strongly suggest a novel role of $\mathrm{IP}_{3} \mathrm{R} 1$-mediated $\mathrm{Ca}^{2+}$ signaling in activity-dependent BDNF production in cerebellar granule cells and its critical functional role on shaping the dendrite arborization of Purkinje cells.

We have shown that of the three subtypes of $\mathrm{IP}_{3} \mathrm{Rs}$, cerebellar granule cells dominantly express $\mathrm{IP}_{3} \mathrm{R} 1$ at least for the first 2 weeks postnatally, which is consistent with our observation of much reduced mGluR-induced $\mathrm{Ca}^{2+}$ release by cerebellar granule cells lacking $\mathrm{IP}_{3} \mathrm{R} 1$ than by WT cells (Fig. 5). A small population of $\mathrm{IP}_{3} \mathrm{R} 1 \mathrm{KO}$ cerebellar granule cells $(\sim 7.0 \%)$ still showed a $\mathrm{Ca}^{2+}$ response to ACPD, and that may be explained by the expression of other types of $\mathrm{IP}_{3} \mathrm{Rs}$, especially $\mathrm{IP}_{3} \mathrm{R} 2$ that is expressed in granule cells at later developmental stages (A. Futatsugi, unpublished data).

Our observation of an abnormal dendritic shape in $\mathrm{IP}_{3} \mathrm{R} 1 \mathrm{KO}$ Purkinje cells conflicts with the finding in a study by Matsumoto and Kato (2001), and the discrepancy may be attributable to the difference in culture conditions. For example, because develop- 
ment of Purkinje cell dendrites depends on the density of granule cells and the concentration of neurotrophic factors and transmitters secreted from surrounding granule cells, a difference in the density of granule cells surrounding Purkinje cells would affect dendritic outgrowth, and, in fact, we observed a tendency toward more branch points and a shorter maximal dendritic length in WT Purkinje cells as the density of the surrounding granule cells increased (data not shown). Cell density in our culture $(\sim 1.5-$ $2.5 \times 10^{6}$ cells $/ \mathrm{cm}^{2}$ ) was much higher than in the other study $\left(\sim 2.0-2.5 \times 10^{5}\right.$ cells $\left./ \mathrm{cm}^{2}\right)$. They also reported no significant alteration in $\mathrm{Ca}^{2+}$ release by $\mathrm{IP}_{3} \mathrm{R} 1 \mathrm{KO}$ cerebellar granule cells in response to mGluR stimulation (Matsumoto and Kato, 2001), which is totally different from our own observation (Fig. 5). Although we have no clear explanation for this discrepancy, it may be explained by the difference in culture conditions or in the developmental stage of the neurons, which may affect the level of expression of $\mathrm{IP}_{3} \mathrm{R} 2$.

Several studies have reported that inhibition of mGluRs leads to changes in the dendritic morphology of Purkinje cells in cerebellar culture. Incubation of Purkinje cells with ( \pm )-amino-4carboxy-methyl-phenylacetic acid (MCPG), a specific inhibitor of group $1 \mathrm{mGluRs}$, resulted in abnormal dendritic morphology (Hirai and Launey, 2000), and the abnormal phenotypes of MCPG-treated Purkinje cells were very similar to those of $\mathrm{IP}_{3} \mathrm{R} 1$ KO Purkinje cells described in this paper, consistent with the notion that $\mathrm{IP}_{3} \mathrm{R}$ is a downstream molecule of group 1 mGluRs. Catania et al. (2001) investigated the role of each subtype of mGluRs in cerebellar culture by using subtype-specific inhibitors of mGluR1 and mGluR5 and found that inhibition of mGluR1 led to a reduction in the viability of Purkinje cells, whereas inhibition of mGluR5 led to changes in the dendritic morphology of Purkinje cells to fewer branch points and longer dendrites. This observation is in good agreement with our conclusion that $\mathrm{IP}_{3} \mathrm{R} 1$ expressed in cerebellar granule cells regulates the dendritic morphology of Purkinje cells, because mGluR5 is expressed in cerebellar granule cells and not in Purkinje cells. The temporal aspects of changes in the dendritic morphology in the study by Catania et al. (2001) and in our own are also consistent. Abnormal dendritic morphology appeared after 9 div in their study and at $\sim 10$ div in our study, around which time granule cells form synapses on Purkinje cells (Schilling et al., 1991).

We have shown that exogenous BDNF rescued the abnormal morphology of $\mathrm{IP}_{3} \mathrm{R} 1 \mathrm{KO}$ Purkinje cells, and that the increase in BDNF production in response to $\mathrm{mGluR}$ and AMPAR stimulation was significantly reduced in $\mathrm{IP}_{3} \mathrm{R} 1 \mathrm{KO}$ cerebellar granule cells. Because the increase in BDNF production by AMPAR stimulation was augmented by costimulation of mGluR (Yuzaki et al., 1994) and $\mathrm{IP}_{3}$ production by G-protein-coupled receptors was greatly increased by costimulation of AMPAR (Baird et al., 1991; del Rio et al., 1994; Nash et al., 2004), it is plausible that AMPAR and mGluR cooperatively activate the signaling pathway for $\mathrm{IP}_{3} \mathrm{R}$-mediated BDNF production. In contrast, it remains unknown how the BDNF produced in cerebellar granule cells regulates the dendritic morphology of Purkinje cells intercellularly. One possibility is that BDNF released by cerebellar granule cells directly regulates the dendritic morphology of Purkinje cells through its receptor (TrkB) expressed on the surface of Purkinje cells. Alternatively, because BDNF is known to increase the probability of transmitter release and to change synaptic shapes (Li et al., 1998; Tyler and Pozzo-Miller, 2001), the glutamate release mechanism in the presynaptic terminals of cerebellar granule cells may be facilitated by BDNF in an autocrine manner, which then affects the dendritic outgrowth of postsynaptic Purkinje cells. A significant enlargement of PSD and presynaptic vesicle accumulation in PF-PC synapse were observed in $\mathrm{IP}_{3} \mathrm{R} 1 \mathrm{KO}$ mice (Fig. $7 B$ ), phenotypes very similar to those observed in BDNF knock-out mice (Carter et al., 2002), supporting the latter alternative. Moreover, the $\mathrm{IP}_{3} \mathrm{R} 1 \mathrm{KO}$ mice exhibited a reduction in paired-pulse facilitation (PPF) at PF-PC synapses, which is an index of presynaptic function [statistically significant when paired-pulse interval was $10 \mathrm{~ms}(p<0.05$; $t$ test $)$, and the $t$ test $p$ values were 0.07 and 0.08 at paired-pulse intervals of 20 and 30 ms, respectively (Matsumoto et al., 1996; our unpublished data)]. A reduction in PPF at PF-PC synapses was also seen in BDNF KO mice (Carter et al., 2002). Because electrical activity in Purkinje cell dendrites makes dendrites stop growing and start to branch (Schilling et al., 1991), the decreased activity-dependent BDNF production in $\mathrm{IP}_{3} \mathrm{R} 1 \mathrm{KO}$ cerebellar granule cells (Fig. $6 C, D$ ) may cause reduced glutamate release from presynapses, leading to the abnormal morphology of $\mathrm{IP}_{3} \mathrm{R} 1 \mathrm{KO}$ Purkinje cells. This idea is further supported by the finding that chronic AMPAR inhibition of cerebellar cultures resulted in increased dendritic outgrowth and fewer branch points (Hirai and Launey, 2000), phenotypes very similar to those of $\mathrm{IP}_{3} \mathrm{R} 1 \mathrm{KO}$ Purkinje cells, and that the occlusive effect of chronic AMPAR blockade was observed in the dendritic morphology of $\mathrm{IP}_{3} \mathrm{R} 1 \mathrm{KO}$ Purkinje cells (our unpublished data). Therefore, the evidence is strong enough to conclude that the BDNF works as an autocrine regulator in cerebellar granule cell for morphogenesis of Purkinje cell dendrites (Fig. 7D).

During the preparation of this manuscript, Furutani et al. (2006) reported that $\mathrm{IP}_{3}$ signaling in Purkinje cells plays a role in strengthening PF-PC synapses presynaptically via BDNF in a retrograde manner (Furutani et al., 2006). Therefore, in addition to the regulation of the axon terminals of granule cells by BDNF in an autocrine manner described here, BDNF from Purkinje cells may also affect presynaptic terminals of granule cells in a retrograde manner. However, judging from the evidence that granule cells, not Purkinje cells, predominantly express BDNF (Wetmore et al., 1990; Castren et al., 1995; Neveu and Arenas, 1996), and our finding in this study that the abnormal morphology of $\mathrm{IP}_{3} \mathrm{R} 1$ KO Purkinje cells was rescued in chimera and overlay cultures with WT cerebellar granule cells, the BDNF produced in granule cells is a major player that modulates the axonal terminals of granule cells.

In summary, we demonstrated that $\mathrm{IP}_{3} \mathrm{R} 1$ in cerebellar granule cells intercellularly regulates the dendritic outgrowth of Purkinje cells through production of BDNF. Our results imply that the huge amount of $\mathrm{IP}_{3} \mathrm{R} 1$ expressed in Purkinje cells does not play a significant role in controlling the dendritic morphology of Purkinje cells. Whether the phenomenon in which the $\mathrm{IP}_{3} \mathrm{R} 1$ expressed in dendrites does not regulate dendritic morphogenesis on-site is specific to Purkinje cells is unclear. Additional studies are expected to shed light on the relationships between the $\mathrm{IP}_{3} \mathrm{R} 1$ functions and dendritic morphogenesis in various types of neurons.

\section{References}

Baird JG, Challiss RA, Nahorski SR (1991) Role for ionotropic and metabotropic receptors in quisqualate-stimulated inositol polyphosphate accumulation in rat cerebral cortex. Mol Pharmacol 39:745-753.

Berridge MJ, Lipp P, Bootman MD (2000) The versatility and universality of calcium signalling. Nat Rev Mol Cell Biol 1:11-21.

Carter AR, Chen C, Schwartz PM, Segal RA (2002) Brain-derived neurotrophic factor modulates cerebellar plasticity and synaptic ultrastructure. J Neurosci 22:1316-1327.

Castren E, Thoenen H, Lindholm D (1995) Brain-derived neurotrophic fac- 
tor messenger RNA is expressed in the septum, hypothalamus and in adrenergic brain stem nuclei of adult rat brain and is increased by osmotic stimulation in the paraventricular nucleus. Neuroscience 64:71-80.

Catania MV, Bellomo M, Di Giorgi-Gerevini V, Seminara G, Giuffrida R, Romeo R, De Blasi A, Nicoletti F (2001) Endogenous activation of group-I metabotropic glutamate receptors is required for differentiation and survival of cerebellar Purkinje cells. J Neurosci 21:7664-7673.

del Rio E, Nicholls DG, Downes CP (1994) Involvement of calcium influx in muscarinic cholinergic regulation of phospholipase $\mathrm{C}$ in cerebellar granule cells. J Neurochem 63:535-543.

Fujii S, Matsumoto M, Igarashi K, Kato H, Mikoshiba K (2000) Synaptic plasticity in hippocampal CA1 neurons of mice lacking type 1 inositol1,4,5-trisphosphate receptors. Learn Mem 7:312-320.

Furuichi T, Mikoshiba K (1995) Inositol 1, 4, 5-trisphosphate receptormediated $\mathrm{Ca}^{2+}$ signaling in the brain. J Neurochem 64:953-960.

Furuichi T, Yoshikawa S, Miyawaki A, Wada K, Maeda N, Mikoshiba K (1989) Primary structure and functional expression of the inositol 1,4,5trisphosphate-binding protein P400. Nature 342:32-38.

Furuichi T, Simon-Chazottes D, Fujino I, Yamada N, Hasegawa M, Miyawaki A, Yoshikawa S, Guenet JL, Mikoshiba K (1993) Widespread expression of inositol 1,4,5-trisphosphate receptor type 1 gene (Insp3r1) in the mouse central nervous system. Receptors Channels 1:11-24.

Furutani K, Okubo Y, Kakizawa S, Iino M (2006) Postsynaptic inositol 1,4,5-trisphosphate signaling maintains presynaptic function of parallel fiber-Purkinje cell synapses via BDNF. Proc Natl Acad Sci USA 103:8528-8533.

Furuya S, Makino A, Hirabayashi Y (1998) An improved method for culturing cerebellar Purkinje cells with differentiated dendrites under a mixed monolayer setting. Brain Res Brain Res Protoc 3:192-198.

Futatsugi A, Nakamura T, Yamada MK, Ebisui E, Nakamura K, Uchida K, Kitaguchi T, Takahashi-Iwanaga H, Noda T, Aruga J, Mikoshiba K (2005) $\mathrm{IP}_{3}$ receptor types 2 and 3 mediate exocrine secretion underlying energy metabolism. Science 309:2232-2234.

Hattori M, Suzuki AZ, Higo T, Miyauchi H, Michikawa T, Nakamura T, Inoue $\mathrm{T}$, Mikoshiba $\mathrm{K}$ (2004) Distinct roles of inositol 1,4,5trisphosphate receptor types 1 and 3 in $\mathrm{Ca}^{2+}$ signaling. J Biol Chem 279:11967-11975.

Hirai H, Launey T (2000) The regulatory connection between the activity of granule cell NMDA receptors and dendritic differentiation of cerebellar Purkinje cells. J Neurosci 20:5217-5224.

Inoue T, Kato K, Kohda K, Mikoshiba K (1998) Type 1 inositol 1,4,5trisphosphate receptor is required for induction of long-term depression in cerebellar Purkinje neurons. J Neurosci 18:5366-5373.

Itoh S, Ito K, Fujii S, Kaneko K, Kato K, Mikoshiba K, Kato H (2001) Neuronal plasticity in hippocampal mossy fiber-CA3 synapses of mice lacking the inositol-1,4,5-trisphosphate type 1 receptor. Brain Res 901:237-246.

Jan YN, Jan LY (2003) The control of dendrite development. Neuron 40:229-242.

Konur S, Ghosh A (2005) Calcium signaling and the control of dendritic development. Neuron 46:401-405.

Kuruma A, Inoue T, Mikoshiba K (2003) Dynamics of $\mathrm{Ca}^{2+}$ and $\mathrm{Na}^{+}$in the dendrites of mouse cerebellar Purkinje cells evoked by parallel fibre stimulation. Eur J Neurosci 18:2677-2689.

Li YX, Zhang Y, Lester HA, Schuman EM, Davidson N (1998) Enhancement of neurotransmitter release induced by brain-derived neurotrophic factor in cultured hippocampal neurons. J Neurosci 18:10231-10240.

Maeda N, Niinobe M, Nakahira K, Mikoshiba K (1988) Purification and characterization of $\mathrm{P} 400$ protein, a glycoprotein characteristic of Purkinje cell, from mouse cerebellum. J Neurochem 51:1724-1730.

Matsumoto M, Kato K (2001) Altered calcium dynamics in cultured cerebellar cells from $\mathrm{IP}_{3} \mathrm{R} 1$-deficient mice. NeuroReport 12:3471-3474.

Matsumoto M, Nakagawa T, Inoue T, Nagata E, Tanaka K, Takano H, Minowa O, Kuno J, Sakakibara S, Yamada M, Yoneshima H, Miyawaki A, Fukuuchi Y, Furuichi T, Okano H, Mikoshiba K, Noda T (1996) Ataxia and epileptic seizures in mice lacking type 1 inositol 1,4,5-trisphosphate receptor. Nature 379:168-171.

Miller FD, Kaplan DR (2003) Signaling mechanisms underlying dendrite formation. Curr Opin Neurobiol 13:391-398.

Nash MS, Willets JM, Billups B, John Challiss RA, Nahorski SR (2004) Synaptic activity augments muscarinic acetylcholine receptor-stimulated inositol 1,4,5-trisphosphate production to facilitate $\mathrm{Ca}^{2+}$ release in hippocampal neurons. J Biol Chem 279:49036-49044.

Neveu I, Arenas E (1996) Neurotrophins promote the survival and development of neurons in the cerebellum of hypothyroid rats in vivo. J Cell Biol 133:631-646.

Nishiyama M, Hong K, Mikoshiba K, Poo MM, Kato K (2000) Calcium stores regulate the polarity and input specificity of synaptic modification. Nature 408:584-588.

Patel S, Joseph SK, Thomas AP (1999) Molecular properties of inositol 1,4,5-trisphosphate receptors. Cell Calcium 25:247-264.

Redmond L, Ghosh A (2005) Regulation of dendritic development by calcium signaling. Cell Calcium 37:411-416.

Schilling K, Dickinson MH, Connor JA, Morgan JI (1991) Electrical activity in cerebellar cultures determines Purkinje cell dendritic growth patterns. Neuron 7:891-902.

Takei K, Shin RM, Inoue T, Kato K, Mikoshiba K (1998) Regulation of nerve growth mediated by inositol 1,4,5-trisphosphate receptors in growth cones. Science 282:1705-1708.

Tyler WJ, Pozzo-Miller LD (2001) BDNF enhances quantal neurotransmitter release and increases the number of docked vesicles at the active zones of hippocampal excitatory synapses. J Neurosci 21:4249-4258.

Wetmore C, Ernfors P, Persson H, Olson L (1990) Localization of brainderived neurotrophic factor mRNA to neurons in the brain by in situ hybridization. Exp Neurol 109:141-152.

Whitford KL, Dijkhuizen P, Polleux F, Ghosh A (2002) Molecular control of cortical dendrite development. Annu Rev Neurosci 25:127-149.

Wong RO, Ghosh A (2002) Activity-dependent regulation of dendritic growth and patterning. Nat Rev Neurosci 3:803-812.

Xiang Y, Li Y, Zhang Z, Cui K, Wang S, Yuan XB, Wu CP, Poo MM, Duan S (2002) Nerve growth cone guidance mediated by G protein-coupled receptors. Nat Neurosci 5:843-848.

Young KW, Garro MA, Challiss RA, Nahorski SR (2004) NMDA-receptor regulation of muscarinic-receptor stimulated inositol 1,4,5-trisphosphate production and protein kinase $\mathrm{C}$ activation in single cerebellar granule neurons. J Neurochem 89:1537-1546.

Yuzaki M, Furuichi T, Mikoshiba K, Kagawa Y (1994) A stimulus paradigm inducing long-term desensitization of AMPA receptors evokes a specific increase in BDNF mRNA in cerebellar slices. Learn Mem 1:230-242. 